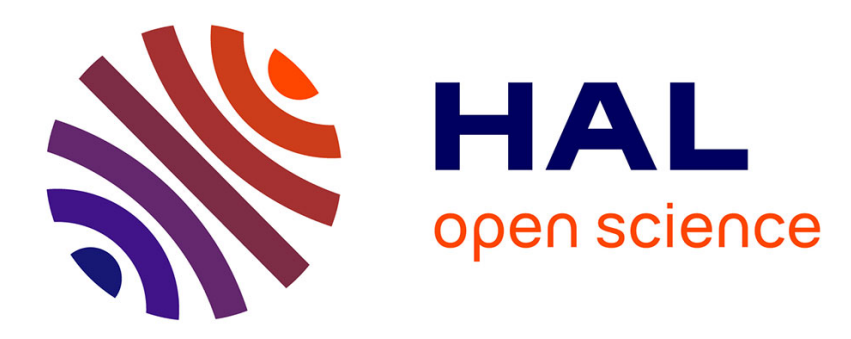

\title{
Plastic deformation of LiNbO3 single crystals
}

\author{
E. Fries, A. Péter
}

\section{To cite this version:}

E. Fries, A. Péter. Plastic deformation of LiNbO3 single crystals. Revue de Physique Appliquée, 1987, 22 (11), pp.1353-1359. 10.1051/rphysap:0198700220110135300 . jpa-00245685

\section{HAL Id: jpa-00245685 https://hal.science/jpa-00245685}

Submitted on 1 Jan 1987

HAL is a multi-disciplinary open access archive for the deposit and dissemination of scientific research documents, whether they are published or not. The documents may come from teaching and research institutions in France or abroad, or from public or private research centers.
L'archive ouverte pluridisciplinaire HAL, est destinée au dépôt et à la diffusion de documents scientifiques de niveau recherche, publiés ou non, émanant des établissements d'enseignement et de recherche français ou étrangers, des laboratoires publics ou privés. 


\title{
Plastic deformation of $\mathrm{LiNbO}_{3}$ single crystals
}

\author{
E. Fries $\left({ }^{*}\right)$ and A. Péter $\left({ }^{* *}\right)$ \\ (*) Laboratoire de Physique des Matériaux, C.N.R.S., 1 place Aristide Briand, 92195 Meudon Cedex, France \\ $\left.{ }^{* *}\right)$ Research Laboratory for Crystal Physics, H.A.S., Budaörsi, ut. 45, 1112 Budapest, Hungary
}

(Reçu le 16 février 1987, révisé le 25 juin 1987, accepté le 20 juillet 1987)

\begin{abstract}
Résumé. - Cet article traite de la déformation plastique à haute température $\left(>0,8 T_{\mathrm{F}}\right)$ de monocristaux de $\mathrm{LiNbO}_{3}$ ferroélectriques et monodomaines. Différentes orientations de la contrainte appliquée ont permis d'activer les glissements basal, prismatique et pyramidal. Une analyse détaillée des éléments de glissement est faite en tenant compte d'observations optiques, par topographie de rayons $\mathrm{X}$, par figures d'attaque aussi bien que de considérations mécaniques (CRSS). Le système de glissement basal (0001) $\langle\overline{1} 2 \overline{1} 0\rangle$ avec une CRSS de $13 \mathrm{MPa}$ semble être activé plus facilement que le système de glissement prismatique $\{11 \overline{2} 0\}\langle\overline{1} 101\rangle$ qui a une CRSS de $15 \mathrm{MPa}$, le système de glissement pyramidal $\{1 \overline{1} 02\}\langle\overline{1} 101\rangle$ avec une CRSS de 17-18 MPa étant le plus difficile à déclencher.
\end{abstract}

\begin{abstract}
High temperature $\left(>0.8 T_{\mathrm{M}}\right.$ ) plastic deformation of ferroelectric monodomain $\mathrm{LiNbO}_{3}$ single crystals is reported. Different stress orientations have been chosen and basal, prismatic and pyramidal glide planes could be activated. A detailed analysis of the glide elements is made by means of optical, chemical etching and X-ray topography observations, as well as mechanical considerations (CRSS). The basal glide system (0001) $\langle\overline{1} 2 \overline{1} 0\rangle$ with a CRSS of $13 \mathrm{MPa}$ seems easier to activate than the prismatic glide system $\{11 \overline{2} 0\}\langle\overline{1} 101\rangle$ whose CRSS is $15 \mathrm{MPa}$, the pyramidal glide system $\{1 \overline{1} 02\}\langle\overline{1} 101\rangle$ with a CRSS of 17$18 \mathrm{MPa}$ being the hardest to activate.
\end{abstract}

\section{Introduction.}

The unique combination of the piezoelectric and optical properties has made lithium niobate $\mathrm{LiNbO}_{3}$ one of the most extensively studied materials in the last twenty years [1]. Its use in broad areas of technological applications necessitates the growth of perfect single crystals ; nowadays they are grown by the Czochralski technique [2].

It is a high temperature ferroelectric material with rhombohedral R3c structure at room temperature and $R \overline{3} \mathrm{c}$ above its Curie point $\left(T_{\mathrm{c}} \sim 1150^{\circ} \mathrm{C}\right)$. The crystal lattice can be described as a distorted hexagonal close-packed configuration and belongs to the broad class of perovskite-related structure [3]. Although a fair amount of work has been devoted to improve the crystal quality and to study the influence of chemical composition on physical properties and defect structures [4], the plastic deformation of $\mathrm{LiNbO}_{3}$ has received scant attention. The deforma- tion twinning and crack nucleation under uniaxial compression have been examined first by Vere, on multi-domain stoichiometric specimens in the temperature range from 1150 to $1250^{\circ} \mathrm{C}$ [5], but without any obvious conclusions about glide except for the basal system. The crystallographic elements of deformation twinning were determined later by Blistanow $[6,7]$.

The aim of the present work is to examine the high temperature plastic deformation in air of $\mathrm{LiNbO}_{3}$ in the ferroelectric phase R3c. We complete and discuss our first results [8] about the determination of the activated glide systems for different uniaxial compression axes.

\section{Experimental procedure.}

2.1 SPECIMEN PREPARATION. - The compression tests reported in this investigation were performed on monodomain specimens cut from good optical 
quality single crystals. The crystals were grown by the conventional Czochralski technique with [0001] growth axis, and congruent melt composition [9]. The poling process was executed at the final stage of growth run. The conversion of the as-grown multidomain structure to single domain by poling was controlled by chemical etching [10]. Testing monodomain samples is important as a multi-domain structure could correspond to «excess twin » [2] inducing cracks during deformation. In view of the various possible slip systems common in h.c.p. structures, five different stress orientations have been selected (Tab. I and Fig. 1). For the orientations $X, Y$ and $45^{\circ} X$ contained in the basal plane prismatic and pyramidal glide could be activated, while for the orientation $36^{\circ} Y$ contained in the $Y O Z$ plane basal and prismatic glide could be activated. Finally $Z$ was chosen in the area where twinning systems could be activated [8].

Table I. - Compression axes $\sigma$ in orthohexagonal and hexagonal conventions.

\begin{tabular}{c|c|c|c|c|c} 
Orthohexag. & $X$ & $Y$ & $Z$ & $36^{\circ} Y$ & $45^{\circ} X$ \\
\hline Hexagonal & $\begin{array}{l}\mathbf{a}_{1} \\
{[2 \overline{1} \overline{1} 0]}\end{array}$ & {$[01 \overline{1} 0]$} & $\begin{array}{c}\text { c } \\
{[0001]}\end{array}$ & {$[02 \overline{2} 1]$} & $\begin{array}{l}45^{\circ} \text { of } a_{1} \\
\text { in }(0001)\end{array}$
\end{tabular}
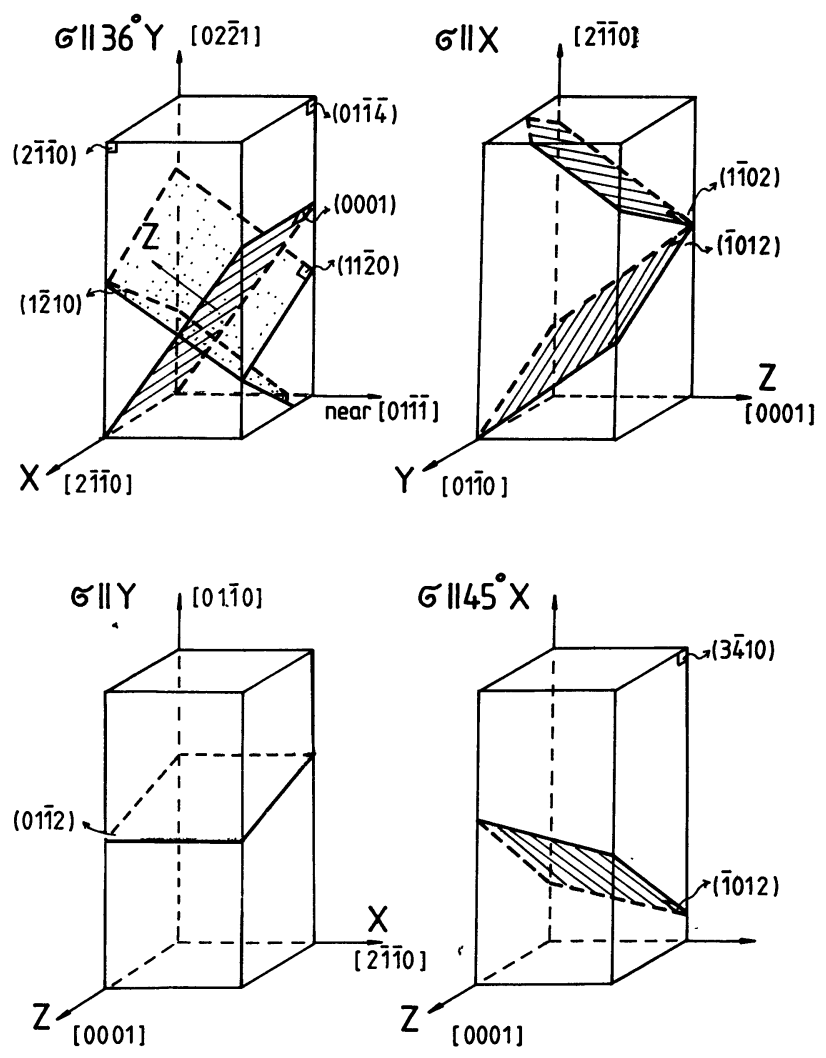

Fig. 1. - $\mathrm{LiNbO}_{3}$ specimens with compressive stress orientations and observed lines corresponding to the slip systems.
2.2 SPECIMEN DEFORMATION. - The experimental conditions have already been described [8]: parallelepiped samples about $4 \times 4 \times 9 \mathrm{~mm}^{3}$ were compressed in air up to $1170{ }^{\circ} \mathrm{C}$ using an Instron machine with a constant cross head velocity of $20 \mu \mathrm{m} / \mathrm{min}\left(\dot{\varepsilon} \sim 3\right.$ to $\left.4 \times 10^{-5} \cdot \mathrm{s}^{-1}\right)$; stress relaxations were also recorded after stopping the crosshead motion.

2.3 SPECIMEN OBSERVATION. - To determine the glide elements, a combination of various techniques was employed : optical observations of the sample shape, slip steps and stress induced birefringence patterns. Chemical etching was used to observe slip traces and also to determine the absolute orientation of the slip planes with respect to the piezo-electrically defined crystal axes $(Y, Z)$. Berg-Barrett topography $[11,12]$ was particularly helpful in the identification of slip traces on faces showing no optical slip steps, since internal stresses due to dislocations give rise to a black « extinction contrast " on $\mathrm{RX}$ topographs. However it could not help for determination of Burgers vectors as this «extinction contrast » still subsists when imaging with various reflecting planes, probably because of multiple slip [13].

\section{Results.}

3.1 Mechanical TeSTS. - Stress-strain curves for different orientations and temperatures were previously given [8], typical curves are recalled figure 2 . Along the $Z$ axis, only mechanical twinning could be obtained, typical oscillations being observed at

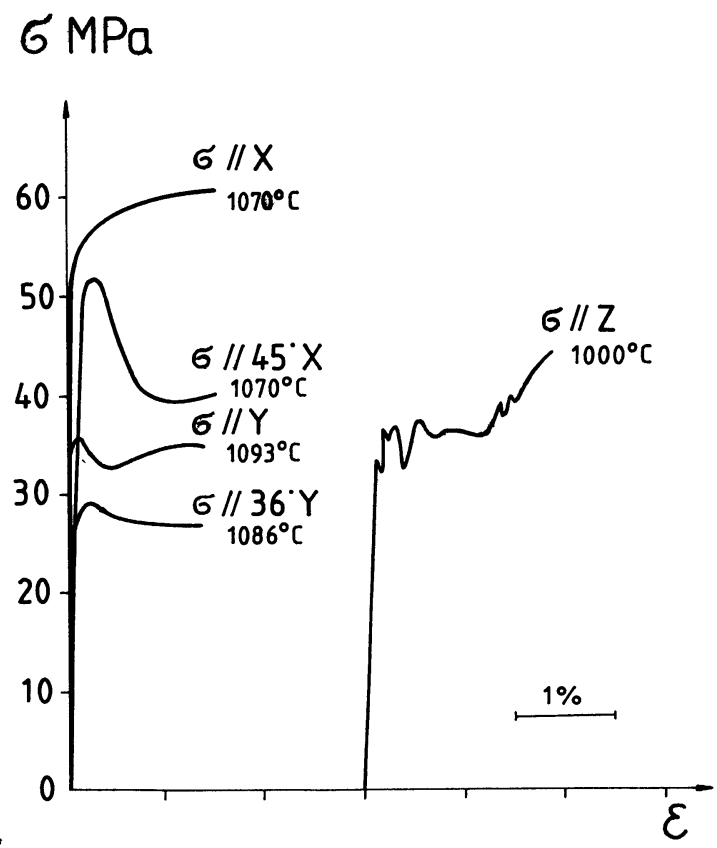

Fig. 2. - Engineering stress $\sigma$ versus engineering strain $\varepsilon$ for compression of $\mathrm{LiNbO}_{3}$ single crystals along different directions. 
$1000{ }^{\circ} \mathrm{C}$ on the stress-strain curve ; the yield stress value is quite independent of temperature (37 MPa for $1000^{\circ} \mathrm{C}, 30 \mathrm{MPa}$ for $1120^{\circ} \mathrm{C}$ ). As expected no evidence of twinning was obtained for the other orientations: plastic deformation could not be achieved below $\sim 1000{ }^{\circ} \mathrm{C}\left(0.8 T_{\mathrm{M}}\right)$ without failure. Yield drops were observed except for the $X$ compression their amplitudes decreasing while increasing temperature [8]. The stress-strain curves exhibit a linear work-hardening stage from $\varepsilon \sim 2 \%$ with low $\theta=\frac{\mathrm{d} \sigma}{\mathrm{d} \varepsilon}$ values : $30 \mathrm{MPa}$ for $\sigma / / 36^{\circ} Y, 50 \mathrm{MPa}$ for $\sigma / / X, 100 \mathrm{MPa}$ for $\sigma / / 45^{\circ} X, 150 \mathrm{MPa}$ for $\sigma / / Y$.

Figure 3 shows the critical yield stress versus temperature $T$ for the different orientations. It can be seen that the softest direction is $36^{\circ} Y$ while the hardest is $X, 45^{\circ} X$ and $Y$ looking very similar.

Analysing stress relaxations gives informations on the thermal activation of the deformation process [14]. At $1050{ }^{\circ} \mathrm{C}$ the mean value of the activation volume is $5.8 \times 10^{-27} \mathrm{~m}^{3}$ which corresponds to 20 $V_{\text {uc }}\left(V_{\text {uc }}=\right.$ hexagonal unit cell volume $=3 \times$ $10^{-28} \mathrm{~m}^{3}$ ) and gives and idea on the volume involved when a dislocation overcomes an obstacle.

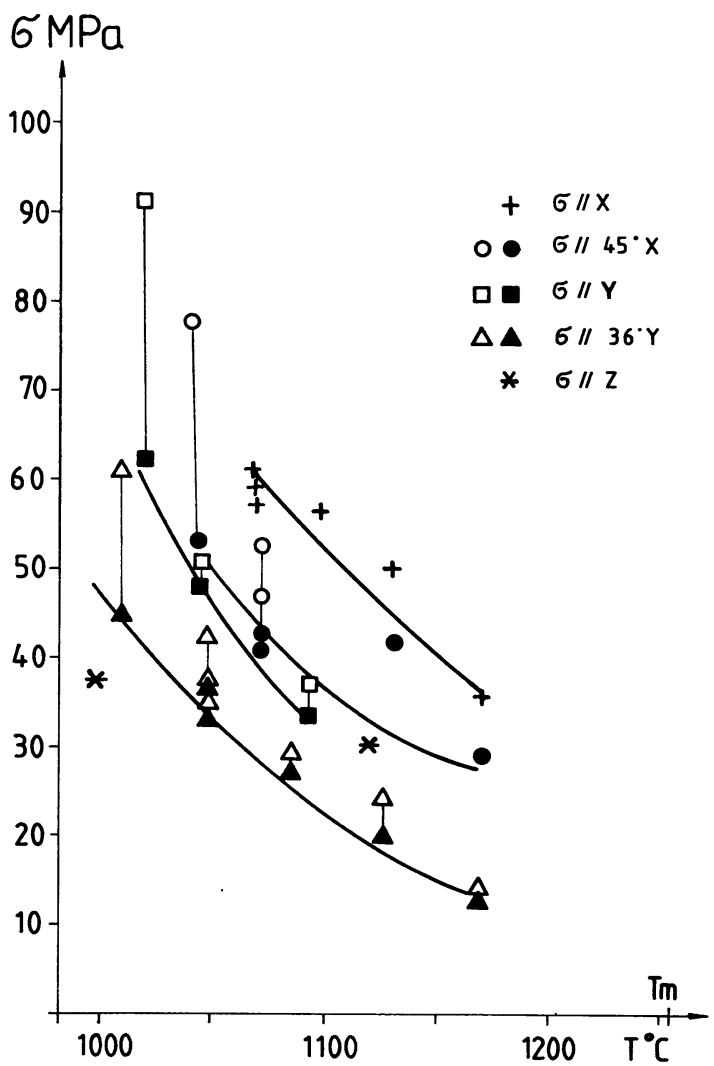

Fig. 3. - Critical Yield stress $\sigma$ versus temperature $T$ for various stress orientations. $\sigma$ is the applied load divided by the initial cross section. In case of a yield drop, the upper and lower stress correspond to the same open and full indications respectively. In the $X$ case we have plotted $\sigma_{0.2}($ for $\varepsilon=0.2 \%) . T_{M}$ is the melting temperature.
3.2 Glide PLANES. - Let us examine the four kinds of specimens where stress orientations give rise to glide : figure 1 shows the orientation of the lateral faces.

- Specimens deformed along the $36^{\circ} Y$ axis exhibited slip steps on both sides, horizontal on the $(01 \overline{1} \overline{4})$ faces which were bent, parallel to OY on the (2110) faces which remained flat. It corresponds to traces of the basal plane (0001). Berg-Barrett topography revealed symmetrical traces at about $54^{\circ}$ from the $36^{\circ} Y$ axis on the $(01 \overline{1} \overline{4})$ face. On the $(2 \overline{1} \overline{1} 0)$ face chemical etching and topography gave the same traces parallel to $\mathrm{OZ}$ (Fig. $4 \mathrm{a}$ and $\mathrm{b}$ ). We deduce prismatic $(11 \overline{2} 0)$ and $(1 \overline{2} 10)$ planes are also activated.
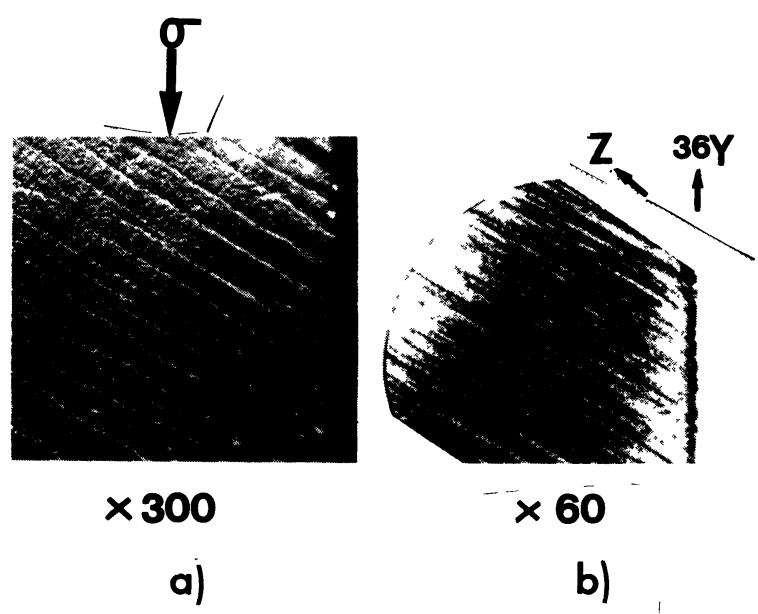

b)

Fig. 4. - a) Etch pits and b) Berg Barrett topography (g [4226] on the $(2 \overline{1} \overline{1} 0)$ face of a $\sigma / / 36^{\circ} Y$ sample after successive compressions at $1170^{\circ} \mathrm{C}$ and $1050{ }^{\circ} \mathrm{C}$, $\varepsilon=4.1 \%$.

- Specimens deformed along the $X$ axis showed symmetrical prominent steps at $60^{\circ}$ from this axis on the (0001) bent faces while on the $(01 \overline{1} 0)$ lateral faces they were fine and symmetrically inclined at about $56^{\circ}$ to the compression axis. These traces correspond to the (1102) and (1012) pyramidal slip planes.

- Specimens deformed along the $Y$ axis showed slip steps only on the (0001) bent faces, these traces being parallel to $O X$. The asymmetrical shape of the (21̄10) faces showed only one slip system had been activated ; Berg-Barrett topography showed lines at about $60^{\circ}$ from [0110]. We could distinguish between $(01 \overline{1} 2)$ and $(0 \overline{1} 12)$ after orientation of the polar axes $Z$ and $Y$ and therefore conclude to the activation of the $(01 \overline{1} 2)$ pyramidal slip plane. 
- Specimens deformed along the $45^{\circ} X$ axis showed slip steps on the (0001) bent faces at about $75^{\circ}$ from this axis. On the $(3 \overline{4} 10)$ faces some lines at $55^{\circ}$ and other at $26^{\circ}$ to the compression axis could be observed. This second set of lines would correspond to very inclined planes about the compression axis whose emergence should be blocked on the compression faces. It is well known that single crystals compressed in orientations for single slip but constrained to maintain coaxial ends show an heterogeneity of the glide strain [15] which could explain an activation of a parasitic glide. Here the asymmetry of the sample shape led us to suppose only one slip system to be operative. Orientation of the polar axes helped us to confirm the (1012) plane was activated.

\section{Discussion.}

4.1 GLIDE SYSTEMS : GENERAL CONSIDERATIONS. The easiest slip direction is in most cases parallel to the closest-packed direction so that the Burgers vector is equal to the shortest lattice repeat distance.

Figure $5(a, b, c)$ shows the lattice structure of $\mathrm{LiNbO}_{3}$ for the low temperature phase R3c. The oxygen atoms are arranged in almost planar sheets forming a network of distorted octahedra. The stacking sequence of cations in octahedral sites along $Z$ axis is $\mathrm{Nb}, \mathrm{V}, \mathrm{Li}, \mathrm{Nb}, \mathrm{V}$... where $\mathrm{V}$ is a vacant site $[3,4]$. The repeat distance along [0001] corresponds to six planes of the h.c.p. sublattice, taking into account the $\mathrm{O}, \mathrm{O}^{\prime}, \mathrm{O}, \mathrm{O}^{\prime} \ldots$ sequence of the closepacked oxygen layers. The $\mathrm{Nb}-\mathrm{O}$ bonding has a partially covalent character while the ionic character of $\mathrm{Li}$ suggests rather homopolar bonds between $\mathrm{Li}-\mathrm{O}$ and $\mathrm{Li}-\mathrm{Nb}$ ions [16].

Table II shows the various possibilities for the Burgers vectors deduced from the crystal structure.

\section{PROJECTION OF THE LINbO ${ }_{3}$ LATTICE}

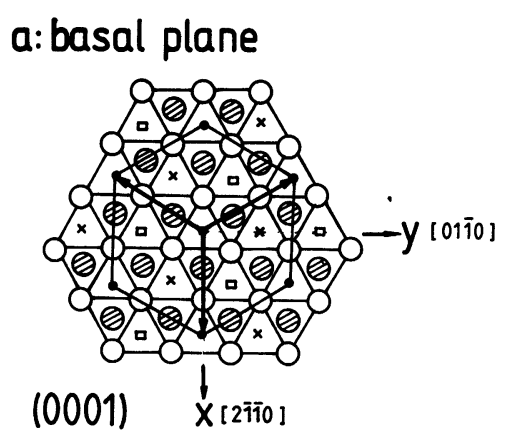

b:prismatic plane

c: pyramidal planes
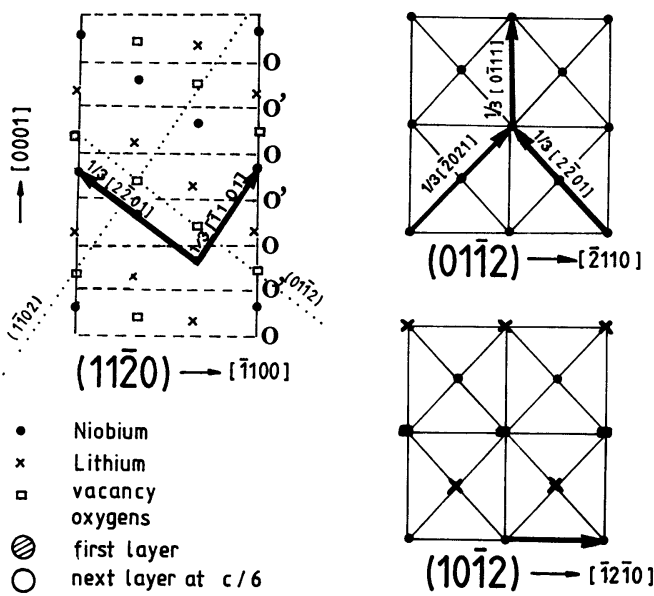

Fig. 5. - Idealized $\mathrm{LiNbO}_{3}$ structure, the hexagonal cell is built on $\mathrm{Nb}$ atoms, a) projection on the basal plane (0001); the basal vector $a=\frac{1}{3}[2 \overline{1} \overline{1} 0]$ is indicated.

b) cation arrangement in a prismatic plane $(11 \overline{2} 0)$; the broken lines indicate planes of oxygen atoms. c) cation arrangement in two different kinds of pyramidal planes $(01 \overline{1} 2)$ and $(10 \overline{1} 2)$.

Table II. - Possible Burgers vectors in the different slip planes.

\begin{tabular}{|c|c|c|c|c|}
\hline b & $b(\mathrm{~nm})$ & plane & & References \\
\hline $\begin{array}{r}1 / 3\langle 2 \overline{1} \overline{1} 0\rangle \\
\langle 0 \overline{1} 10\rangle\end{array}$ & $\begin{array}{l}0.515 \\
0.892\end{array}$ & $\begin{array}{l}\text { basal } \\
\text { basal }\end{array}$ & $\begin{array}{l}\text { perfect } \\
\text { perfect }\end{array}$ & [17] $\left\{\begin{array}{l}\text { Direction determined } \\
\text { by decoration }\end{array}\right.$ \\
\hline $\begin{array}{c}1 / 3\langle\overline{1} 101\rangle \\
1 / 3\langle 2 \overline{2} 01\rangle \\
{[0001]} \\
\langle\overline{1} 100\rangle\end{array}$ & $\begin{array}{l}0.549 \\
0.74 \\
1.386 \\
0.892\end{array}$ & $\begin{array}{l}\text { prismatic } \\
\text { prismatic } \\
\text { prismatic } \\
\text { prismatic }\end{array}$ & $\begin{array}{l}\text { perfect } \\
\text { perfect } \\
\text { perfect } \\
\text { perfect }\end{array}$ & $\begin{array}{l}{[18]\left\{\begin{array}{l}\text { Directions determined } \\
\text { by topography }\end{array}\right.}\end{array}$ \\
\hline $\begin{array}{l}1 / 3\langle\overline{1} 101\rangle \\
1 / 3\langle 2 \overline{2} 01\rangle \\
1 / 3\langle\overline{1} 2 \overline{1} 0\rangle\end{array}$ & $\begin{array}{l}0.549 \\
0.74 \\
0.515\end{array}$ & $\begin{array}{l}\text { pyramidal } \\
\text { 1st kind } \\
\left\{\begin{array}{l}\text { pyramidal } \\
\text { 1st kind }\end{array}\right. \\
\left\{\begin{array}{l}\text { pyramidal } \\
2 \text { nd kind }\end{array}\right.\end{array}$ & $\begin{array}{l}\text { perfect } \\
\text { perfect } \\
\text { perfect }\end{array}$ & [19] $\left\{\begin{array}{l}\text { B. vector by M.E.T. } \\
\text { and computer simulation }\end{array}\right.$ \\
\hline
\end{tabular}


Only glide directions have been observed in most cases $[17,18]$ except for $1 / 3\langle\overline{1} 101\rangle$ where Burgers vectors have been identified by means of computer simulation of their contrast [19]. The Burgers vector $1 / 6\langle 2 \overline{2} 01\rangle$ previously reported [18] is not indicated here as it does not correspond to a perfect dislocation if one takes into account the $\mathrm{O}, \mathrm{O}^{\prime}, \mathrm{O}, \mathrm{O}^{\prime} \ldots$ sequence of the oxygen layers.

4.2 Glide SYSTEMS. - Let us now try to determine the glide systems consistently with our previous results (Fig. 1 and Tab. II). We consider short Burgers vectors as more favourable, elastic strain energies of dislocations being proportional to $b^{2}$ in a first approximation.

4.2.1 Basal glide system. - The vector $1 / 3\langle 2 \overline{1} \overline{1} 0\rangle$ is the shortest repeat distance of the cationic lattice, $\langle 0 \overline{1} 10\rangle$ is a close packed direction in the oxygen arrangement. In the case of the $\sigma / / 36^{\circ} Y$ compression we took into account the slip directions giving

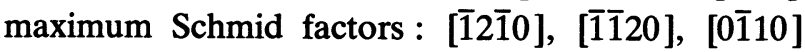
(Tab. III). The last one can be eliminated as the glide direction cannot be parallel to the macroscopic steps (see. 3.2). Then are left the 2 possibilities shown table IV.

4.2.2 Prismatic glide system. - The $1 / 3\langle\overline{1} 101\rangle$ and $1 / 3\langle 2 \overline{2} 01\rangle$ Burgers vectors are rather short $0.549 \mathrm{~nm}$ and $0.74 \mathrm{~nm},[0001]$ and $\langle\overline{1} 100\rangle$ have also to be considered as potential Burgers vectors on these planes. In the $\sigma / / 36^{\circ} Y$ compression, prismatic slip planes $(11 \overline{2} 0)$ and $(1 \overline{2} 10)$ have been observed. Chemical etching and Berg-Barrett topography on the same $(2 \overline{1} \overline{1} 0)$ face are shown figure 4 (a and $b)$.

Table III. - $\mathrm{LiNbO}_{3}$ Schmid factors for different slip systems in specimens with various compression axis $\sigma$.

\begin{tabular}{|c|c|c|c|c|c|c|}
\hline $\begin{array}{l}\text { slip } \\
\text { plane }\end{array}$ & $\begin{array}{l}\text { slip } \\
\text { direction }\end{array}$ & $\begin{array}{c}\sigma / / Z \\
Z=[0001]\end{array}$ & $\begin{array}{c}\sigma / / X \\
X=[2 \overline{1} \overline{1} 0]\end{array}$ & $\begin{array}{c}\sigma / / Y \\
Y=[01 \overline{1} 0]\end{array}$ & $\begin{array}{c}\sigma / / 36^{\circ} Y \\
36^{\circ} Y=[02 \overline{2} 1]\end{array}$ & $\mid \sigma / / 45^{\circ} X$ \\
\hline$(01 \overline{1} 2)$ & $\begin{array}{l}{[0 \overline{1} 11]} \\
{[2 \overline{2} 01]} \\
{[\overline{2} 021]}\end{array}$ & $\begin{array}{l}0.45 \\
0.33 \\
0.33\end{array}$ & $\begin{array}{l}0 \\
0 \\
0\end{array}$ & $\begin{array}{l}0.45 \\
0.33 \\
0.33\end{array}$ & $\begin{array}{l}0.08 \\
0.06 \\
0.06\end{array}$ & $\begin{array}{l}0.23 \\
0.11 \\
0.46\end{array}$ \\
\hline$(1 \overline{1} 02)$ & $\begin{array}{l}{[\overline{1} 101]} \\
{[02 \overline{2} 1]} \\
{[\overline{2} 021]}\end{array}$ & $\begin{array}{l}0.45 \\
0.33 \\
0.33\end{array}$ & $\begin{array}{l}0.34 \\
0 \\
0.49\end{array}$ & $\begin{array}{l}0.11 \\
0.33 \\
0.16\end{array}$ & $\begin{array}{l}0 \\
0 \\
0\end{array}$ & $\begin{array}{l}0.02 \\
0.11 \\
0.15\end{array}$ \\
\hline (1̄012) & $\begin{array}{l}{[10 \overline{1} 1]} \\
{[2 \overline{2} 01]} \\
{[02 \overline{2} 1]}\end{array}$ & $\begin{array}{l}0.45 \\
0.33 \\
0.33\end{array}$ & $\begin{array}{l}0.34 \\
0.49 \\
0\end{array}$ & $\begin{array}{l}0.11 \\
0.16 \\
0.33\end{array}$ & $\begin{array}{l}0 \\
0 \\
0\end{array}$ & $\begin{array}{l}0.42 \\
0.15 \\
0.46\end{array}$ \\
\hline$(11 \overline{2} 0)$ & $\begin{array}{l}{[\overline{1} 101]} \\
{[2 \overline{2} 01]} \\
{[0001]} \\
{[\overline{1} 100]}\end{array}$ & $\begin{array}{l}0 \\
0 \\
0 \\
0\end{array}$ & $\begin{array}{l}0.23 \\
0.34 \\
0 \\
0.43\end{array}$ & $\begin{array}{l}0.23 \\
0.34 \\
0 \\
0.43\end{array}$ & $\begin{array}{l}0.49 \\
0.04 \\
0.42 \\
0.26\end{array}$ & $\begin{array}{l}0.12 \\
0.18 \\
0 \\
0.23\end{array}$ \\
\hline$(\overline{2} 110)$ & $\begin{array}{l}{[0 \overline{1} 11]} \\
{[02 \overline{2} 1]} \\
{[0001]} \\
{[0 \overline{1} 10]}\end{array}$ & $\begin{array}{l}0 \\
0 \\
0 \\
0\end{array}$ & $\begin{array}{l}0 \\
0 \\
0 \\
0\end{array}$ & $\begin{array}{l}0 \\
0 \\
0 \\
0\end{array}$ & $\begin{array}{l}0 \\
0 \\
0 \\
0\end{array}$ & $\begin{array}{l}0.27 \\
0.39 \\
0 \\
0.5\end{array}$ \\
\hline$(1 \overline{2} 10)$ & $\begin{array}{l}{[10 \overline{1} 1]} \\
{[\overline{2} 021]} \\
{[0001]} \\
{[10 \overline{1} 0]}\end{array}$ & $\begin{array}{l}0 \\
0 \\
0 \\
0\end{array}$ & $\begin{array}{l}0.23 \\
0.34 \\
0 \\
0.43\end{array}$ & $\begin{array}{l}0.23 \\
0.34 \\
0 \\
0.43\end{array}$ & $\begin{array}{l}0.49 \\
0.04 \\
0.42 \\
0.26\end{array}$ & $\begin{array}{l}0.14 \\
0.21 \\
0 \\
0.26\end{array}$ \\
\hline$(0001)$ & $\begin{array}{l}{[2 \overline{1} \overline{1} 0]} \\
{[\overline{1} 2 \overline{1} 0]} \\
{[\overline{1} \overline{1} 20]} \\
{[0 \overline{1} 10]} \\
{[\overline{1} 010]} \\
{[\overline{1} 100]}\end{array}$ & $\begin{array}{l}0 \\
0 \\
0 \\
0 \\
0 \\
0\end{array}$ & $\begin{array}{l}0 \\
0 \\
0 \\
0 \\
0 \\
0\end{array}$ & $\begin{array}{l}0 \\
0 \\
0 \\
0 \\
0 \\
0\end{array}$ & $\begin{array}{l}0 \\
0.42 \\
0.42 \\
0.48 \\
0.23 \\
0.23\end{array}$ & $\begin{array}{l}0 \\
0 \\
0 \\
0 \\
0 \\
0\end{array}$ \\
\hline
\end{tabular}


Evidence of cross slip between the slip traces can be seen in figure $4 \mathrm{~b}$. As cross slip proceeds by screw dislocations whose Burgers vector is parallel to the dislocation line, one can eliminate b [0001] as a dislocation line in the $(2 \overline{1} \overline{1} 0)$ face would not be

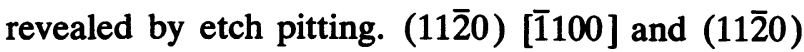
[22̄01] were not considered for having smaller Schmid factor ( 0.26 and 0.04 respectively). The most probable glide systems are finally $(11 \overline{2} 0)[\overline{1} 101]$ and

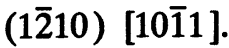

4.2.3 Pyramidal glide system. - Such a pyramidal glide was observed for $\sigma / / X, \sigma / / 45^{\circ} X$ and $\sigma / / Y$. One notices two different kinds of pyramidal planes (Fig. 5c) as a consequence of the three fold rotation symmetry about the $c$ axis. In the present case the

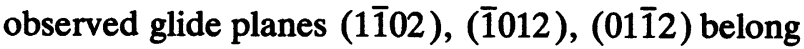
to the first kind; the possible Burgers vectors are therefore $1 / 3\langle\overline{1} 101\rangle$ and $1 / 3\langle 2 \overline{2} 01\rangle$.

For $\sigma / / X$, the Schmid factor equals 0 for (11̄02) [02 $\overline{2} 1]$ and $(\overline{1} 012)[02 \overline{2} 1]$; prominent traces on the (0001) face lead us to conclude the glide direction to be near the $\{01 \overline{1} 0\}$ face which is the case for $\langle\overline{1} 101\rangle\left(15^{\circ}\right.$ from the intersection of the glide plane and the surface). The glide systems are therefore

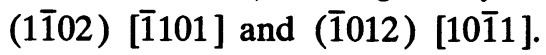

For $\sigma / / 45^{\circ} X$, the same kind of pyramidal plane being gliding (Fig. 5c), the same kind of system is probably activated in this case (1012) [1011].

For $\sigma / / Y$, the $(2 \overline{1} \overline{1} 0)$ face remaining flat without any slip traces, one can suppose the slip direction lies in this plane, the only possible Burgers vector is then

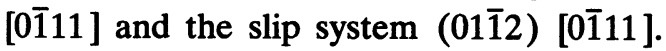

Our conclusions about slip systems are displayed in table IV. Note that, for such a low symmetry

Table IV. - Slip systems and their corresponding critical resolved shear stress (CRSS) for $\mathrm{LiNbO}_{3}$ compressed along various directions.

\begin{tabular}{c|c|c|c}
$\sigma / /$ & $\begin{array}{c}\text { slip } \\
\text { planes }\end{array}$ & $\begin{array}{c}\text { slip } \\
\text { directions }\end{array}$ & $\begin{array}{c}\text { CRSS (MPa) } \\
\text { at } 1070{ }^{\circ} \mathrm{C}\end{array}$ \\
\hline $36^{\circ} Y[02 \bar{\Sigma} 1]$ & $(0001)$ & {$[\overline{1} 2 \overline{1} 0],[\overline{1} \overline{1} 20]$} & 13 \\
& $(1 \overline{\overline{1}}(101])$ & 15 \\
$(1 \overline{2} 10)$ & {$[10 \overline{1} 1]$} & 15 \\
\hline$X[2 \overline{1} \overline{1} 0]$ & $(1 \overline{1} 02)$ & {$[\overline{1} 101]$} & 20 \\
& $(\overline{1} 012)$ & {$[10 \overline{1} 1]$} & 20 \\
\hline$Y[01 \overline{1} 0]$ & $(01 \overline{1} 2)$ & {$[0 \overline{1} 11]$} & 18 \\
\hline $45^{\circ} X$ & $(\overline{1} 012)$ & {$[10 \overline{1} 1]$} & 17
\end{tabular}

structure, glide directions or their reverse are not always crystallographically equivalent [20]. This is the case for prismatic and pyramidal slip systems, but it is not clear if it has some consequence on plastic deformation.

4.3 GLIDE SYSTEMS AND PLASTIC DEFORMATION. When deforming a crystal along different directions, we may activate the same slip system ; then the yield stresses $\left(\sigma_{1} \sigma_{2}\right)$ must be in the inverse ratio of the Schmid factors $\left(f_{1}, f_{2}\right)$.

$$
\frac{\sigma_{2}}{\sigma_{1}}=\frac{f_{1}}{f_{2}} .
$$

Let us investigate if the same system (1012) [10111] could have been activated in the $45^{\circ} X$ and $X$ compression as we suppose previously. Their yield stress-temperature behaviours are similar (Fig. 3) ; at $1070^{\circ} \mathrm{C}$ we calculate $\frac{\sigma_{2}}{\sigma_{1}}=0.7$, and $\frac{f_{1}}{f_{2}}=0.8$ which is consistent with an activation of the same system. This would not have been the case for

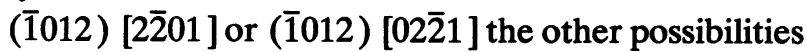
for pyramidal glide systems which give respectively $\frac{f_{1}}{f_{2}}=3.2$ and 0 .

Let us now examine the different slip systems in terms of critical resolved shear stress (CRSS Tab. IV) $\tau=\sigma f(\tau$ : shear stress, $f$ : Schmid factor $)$. If a hard slip plane is activated, the shear stress on softer slip planes must always remain below its CRSS. At $1070^{\circ} \mathrm{C}$ the CRSS values for $\sigma / / 36^{\circ} \mathrm{Y}$ are the smallest : both basal slip systems (0001) [1링 or (0001) [11120] possess a Schmid factor equal to 0 for all the other orientations, and could not then be activated. The prismatic system $\{11 \overline{2} 0\}\langle\overline{1} 101\rangle$ has not been activated for the other compression axes : for the $Y$ and $45^{\circ} X$ compression axes its resolved shear stresses ( $9 \mathrm{MPa}$ and $5 \mathrm{MPa}$ ) are below its CRSS (15 MPa), this is not the case for the $X$ axis where a resolved shear stress of $14 \mathrm{MPa}$ could be within the experimental scattering of the CRSS $( \pm 5 \%)$. The pyramidal system $\{1 \overline{1} 02\}\langle\overline{1} 101\rangle$ has been activated for the $Y, 45^{\circ} X$ and $X$ compressions. The different CRSS values (17-18 and $20 \mathrm{MPa}$ respectively) can be considered in agreement within the experimental scattering.

4.4 COMPARISON WITH GLIDE SYSTEMS IN ALUMINA. - Alumina has also a h.c.p. structure with similar c/a ratio and similar packing sequences of cations in the octahedral sites. However alumina is centrosymmetric $(\mathrm{R} \overline{3} \mathrm{C})$ while ferroelectric $\mathrm{LiNbO}_{3}$ has a lower symmetry structure (R3C). Comparison has then to be made with some precaution, but it is 
nevertheless interesting as glide systems are fairly well known for alumina [21, 22].

The same systems have been activated for basal and pyramidal glides. However prismatic and not pyramidal glide is activated for the same stress orientations in alumina as in $\mathrm{LiNbO}_{3}$. Concerning prismatic glide the Burgers vectors are different : $\langle 10 \overline{1} 0\rangle$ for alumina, and $\langle\overline{1} 101\rangle$ for $\mathrm{LiNbO}_{3}$.

\section{Conclusions and summary.}

Plastic deformation of ferroelectric monodomain $\mathrm{LiNbO}_{3}$ single crystals has been carried out at $T>0.8 T_{M}$ for various stress orientations. At such high temperatures deformation is rather isotropic: basal glide (0001) $\langle\overline{1} 2 \overline{1} 0\rangle$ with a CRSS of $13 \mathrm{MPa}$ at $1070{ }^{\circ} \mathrm{C}$ is the easiest to activate. Prismatic and pyramidal systems with CRSS of $15 \mathrm{MPa}$ and 17-18 $\mathrm{MPa}$ at $1070^{\circ} \mathrm{C}$ have the same glide directions $\langle\overline{1} 101\rangle$. Only one kind of pyramidal planes has been activated, the same as for cleavage. This work is self consistent but will be completed by transmission electron microscopy studies.

\section{Acknowledgments.}

The authors wish to thank J. Castaing and J. Janszky for helpful discussions. They are also grateful to $\mathrm{J}$. Deschamps for technical assistance and K. Polgar for growing the crystals. Part of this work was supported by a cooperation research program between Hungarian Academy of Sciences and Centre National de la Recherche Scientifique and by the R.C.P. « Perovskites à Hautes Températures».

\section{References}

[1] Weis, R. S., Gaylord, T. K., Appl. Phys. A 37 (1985) 191.

[2] NIIZEKI, N., Growth and characterization of ferroelectric crystals, in Crystal Growth Characterization, Eds. R. Ueda and J. B. Mullin (North Holland, Amsterdam) 1975, p. 97.

[3] Megaw, H. D., Darlington, C. N. W., Acta Crystallogr. (1975) 161.

[4] Rauber, A., Chemistry and Physics of lithium niobate. Current Topics in Materials Sciences, Ed. E. Kaldis (North Holland PC) 1978 vol. 1, p. 481.

[5] Vere, A. W., J. Mat. Sci. 3 (1968) 617.

[6] Blistanov, A. A., Nosova, I. V., Tagieva, M. M., Kristallografiya 20 (1975) 666.

[7] Blistanov, A. A., Nosova, I. V., Tagieva, M. M., Kristallografiya 21 (1976) 217.

[8] Fries, E., Deschamps, J., Peter, A., Polgar, K., Cryst. Lattice Defects Amorph. Mat. 1986 to be published (Proceedings of the 5th Europhysical Topical Conference on Lattice Defects in ionic crystals.

[9] Polgar, K., Jeszenszky, L., Rakasanyi, K., Hartmann, E., Acta Phys. Hung. 47 (1979) 125.

[10] Nassau, K., Levinstein, H. J. and Loicono, G. M., J. Phys. Chem. Solids 27 (1966) 983.
[11] Newkirk, J. B., Trans. Metal. Soc. A.I.M.E. USA 215 (1959) 483.

[12] Fries, E., Marhic, C., Bretheau, T., J. Physique Colloq. 37 (1976) C7-572.

[13] Fries, E., Spendel, M. and Philibert, J., J. Appl. Crystallogr. 14 (1981) 285.

[14] Bretheau, T., Castaing, J., Rabier, J. and VeySSIERE, P., Adv. Phys. 28 (1979) 829.

[15] Castaing, J., Cadoz, J., Kirby, S. H., J. Am. Ceram. Soc. 64 (1981) 504.

[16] Abrahams, S. C., Levinstein, H. J., RedDy, J. M., J. Phys. Chem. Solids 27 (1966) 1019.

[17] Levinstein H. J., Capio, C. D., J. Appl. Phys. 38 (1967) 2761.

[18] Okada, Y., Iizuka, T., J. Appl. Crystallogr. 9 (1976) 375.

[19] Cerva, H., Pongratz, P., Skalicky, P., Philos. Mag. A 54 (1986) 185.

[20] Kelly, A., Groves, G. W., Crystallography and Crystal Defects (Ed. Longman) 1970, p. 173.

[21] Lagerlöf, K. D. P., Mitchell, T. E., Heuer, A. H., Riviere, J. P., Cadoz, J., Castaing, J., Phillips, D. S., Acta Met. 32 (1984) 97.

[22] Heuer, A. H., Castaing, J., Adv. Ceram. 10 (1985) 238. 